\title{
Bibliographical Essay
}

The study of propaganda requires a multidisciplinary approach, but as the emphasis of this book is historical I have relied on a wide variety of works too numerous to mention here. Wherever possible, I have used primary source materials (in translation when available), such as Roman inscriptions and the works of classical historians, medieval songs and chronicles, modern printed propaganda, film and documentary evidence, and television.

Certain general works are useful starting points, such as Oliver Thomson's illustrated Mass Persuasion in History (1977) and Anthony Rhodes's Propaganda (1976). A seminal work by a sociologist is Jacques Ellul, Propaganda: The Formation of Men's Attitudes (1957), but the same author's The Technological Society (1964) is an invaluable compendium. More recently, two psychologists have tackled the subject from a contemporary point of view in Anthony Pratkanis and Elliot Aronson, Age of Propaganda: The Everyday Use and Abuse of Persuasion (1991). Another psychological perspective is offered by G.H. Jamieson, Communication and Persuasion (1985). Guy Arnold's Brainwash: The Cover-up Society (1992) is better than its title. The best single-volume introduction is edited by 'old masters' Harold Lasswell, Daniel Lerner and Hans Speier, Propaganda and Communication in World History (1979). Other invaluable works include T.H. Qualter's Propaganda and Psychological Warfare (1962) and his Opinion Control in the Democracies (1985), Elias Canetti's Crowds and Power (1963), Sam Keen's Face of the Enemy (1986), F.H. Hartmann's The Conservation of Enemies (1982), Garth Jowett and Victoria O'Donnell's Propaganda and Persuasion (1986) and Charles Roetter's Psychological Warfare (1974). I, personally, dislike Laurence Rees's Selling Politics (1992); the BBC TV programmes it was written to accompany ('We Have Ways of Making You Think') were better. No 
examination of this topic can avoid Walter Lippmann's seminal Public Opinion (1922). Useful approaches to related persuasive techniques such as advertising include: A. \& J. Trout, Positioning: The Battle For Your Mind (1987), S. Fox, The Mirror Makers (1984) and W. Schramm (ed.), The Science of Human Communication (1963). Vance Packard's The Hidden Persuaders (1957) was the classic of its time about advertising, as was J.A.C. Brown's Techniques of Persuasion (1963).

General histories of warfare rarely give much attention to propaganda, but certain key works provide invaluable insights for the student of propaganda and morale. These are H.W. Koch's illustrated History of Warfare (1987), Sir Michael Howard's War in European History (1973), Michael Waltzer's Just and Unjust Wars (1977), Geoffrey Best's Humanity in Warfare (1980) and John Keegan's History of Warfare (1993). The latter is a useful corrective to studies of war dominated by Clausewitzian theories.

For the ancient period Arthur Ferrill's The Origins of War (1985), W.K. Pritchett's The Greek State at War (2 vols, 1971, 1974), W.W. Tarn's Alexander the Great (1948), Sir Ronald Syme's The Roman Revolution (1939) and J.F. Gardner's Leadership and the Cult of Personality (1974). Essential studies of ancient uses of persuasion are: M. Billig, Arguing and Thinking (1987), G.A. Kennedy, The Art of Persuasion in Greece (1972) and his more recent Classical Rhetoric (1980). An important new contribution is Anton Powell, Roman Poetry and Propaganda in the Age of Augustus (1992).

Michael McCormick's Eternal Victory: Triumphal Rulership in Late Antiquity, Byzantium and the Early Medieval West (1986), though highly specialized, is an important contribution to our knowledge of ceremony and ritual in the Dark Ages.

For the medieval period, J.F. Verbruggen's The Art of Warfare in Western Europe during the Middle Ages (1977) is invaluable as it attempts to examine the psychological aspects of warfare, particularly for the later Middle Ages. Phillipe Contamine's War in the Middle Ages, first published in France in 1980, provides an even more general view. John Beele's Warfare in Feudal Europe, 730-1200 (1971) is a good introductory work. For the Norman Conquest, R. Allen Brown's edition of documents, The Norman Conquest (1984) is essential. For the Crusades, T.P. Murphey's edition of papers, The Holy War (1976) is also valuable. For the fifteenth century, see Malcolm Vale's War and Chivalry (1981). Two documentary compilations provide insights into contemporary views: Louise and Jonathan Riley-Smith's The Crusades: Idea and Reality 1095-1274 (1981) and the older The Crusades: A Documentary Survey, edited by James A. 
Brundage (1962).

For the early modern period, J.R. Hale's War and Society in Renaissance Europe (1985) is an excellent introduction. By far the most useful work on printing is Elizabeth Eisenstein's two-volume masterpiece, The Printing Press as an Agent of Change (1979). On early Tudor propaganda, Sydney Angelo's Spectacle, Pageantry and Early Tudor Policy (1969) remains invaluable, as does C.E. Challis's The Tudor Coinage (1978). Sir Geoffrey Elton's Policy and Police (1972) contains a chapter on Thomas Cromwell's propaganda activities. Roy Strong has provided the most useful examination of Elizabethan propaganda in his The Cult of Elizabeth (1977), which should be read in conjunction with his earlier works, Portraits of Queen Elizabeth I (1963), The English Icon: Elizabethan and Jacobean Portraiture (1969) and Tudor and Jacobean Portraits (1969). See also P. Erlanger's The Age of Courts and Kings (1967). On Elizabeth's military affairs, see C.G. Cruikshank, Elizabeth's Army (1946). The Thirty Years War is best dealt with by two works, Herbert Langer's 1978 book of that title and the older book by E.A. Beller, Propaganda in Germany during the Thirty Years War (1940). Henry Kamen's European Society, 1500-1700 (1984) provides useful background and insights into the period as a whole. The best work on France in this period is Joseph Klaits, Printed Propaganda under Louis XIV (1976). G. Boyce, J. Curran and P. Wingate have edited a useful collection on the origins and development of the press, Newspaper History from the 17th Century to the Present Day (1978), which also contains a valuable bibliography. Tim Harris's London Crowds in the Reign of Charles II (1987) is a model for microcosmic studies in the early modern period; George Rudé's, The Crowd in History (1964) remains a classic.

On the American Revolution see Carl Berger, Broadsides and Bayonets: The Propaganda War of the American Revolution (1961), Solomon Lutnicj, The American Revolution and the British Press, 1775-83 (1967), Kenneth Silverman, A Cultural History of the American Revolution (1976), and D.M. Clark, British Opinion and the American Revolution (1930). Still useful are Philip Davidson, Propaganda and the American Revolution (1941) and Arthur Schlesinger, Prelude to Independence: the Newspaper War in Britain (1958). On the French revolutionary period, attention is still drawn to Robert Holtman's Napoleonic Propaganda (1950), M. Agulhon's Marianne into Battle (1981) and Clive Emsley's British Society and the French Wars (1979).

For the nineteenth century, Philip Knightley's The First Casualty: The War Correspondent as Hero, Myth-maker and Propagandist (1975) 
remains as good a starting point as any, especially on war correspondents and censorship, and John Mackenzie's Propaganda and Empire, 18801960 (1984) throws much new light on the British scene. On censorship, see R.J. Goldstein, Political Censorhip of the Arts and the Press in 19th Century Europe (1989).

For the twentieth century, there is a veritable wealth of published works far too numerous to mention here. Much has been pioneered in the works of Nicholas Pronay. The shortest available introduction is Ken Ward's Mass Communications and the Modern World (1989). However, certain important works cannot be overlooked, most notably Michael Balfour, Propaganda in War 1939-45 (1978), Nicholas Reeves, Official British Film Propaganda in the First World War (1986), N. Pronay and D.W. Springs (eds), Propaganda, Politics and Film, 1918-45 (1982), K.R.M. Short, Film and Radio Propaganda in the Second World War (1983), Richard Taylor, Film Propaganda (1979), Robert E. Herzstein, The War that Hitler Won (1979), C.R. Koppes and G.D. Black, Hollywood Goes to War (1987), J. Leyda, Kino (1960), P. Kenez, The Birth of the Propaganda State (1985), Anthony Aldgate and Jeffrey Richards, Britain Can Take It (1986), David Welch, The Third Reich: Politics and Propaganda (1993) and Clive Coultass, Images for Battle (1989).

Since this book first appeared in 1990, several major new contributions have appeared. Philip Bell made an important contribution to our knowledge of the Second World War propaganda with John Bull and the Bear: British Public Opinion, Foreign Policy and the Soviet Union, 194145 (1990) and an important American work is by H. Winkler, The Censored War: American Visual Experience in World War Two (1992). The First World War has received new contributions in the form of P. Buitenhuis, The Great War of Words: Literature as Propaganda, 1914-18 and After (1989) and Gary Messinger, British Propaganda and the State in the First World War (1992). Both acknowledge, as all works dealing with the First World War must do, the earlier work of Harold Lasswell, Propaganda Technique in the World War (1927). Lord Ponsonby's bestselling Falsehood in Wartime (1927) provides an indication of popular misconception of the real nature of propaganda.

The Cold War has received recent attention in Fred Inglis, The Cruel Peace: Living through the Cold War (1991) and Robert B. Bathurst, Intelligence and the Mirror: On Creating an Enemy (1993). Black radio propaganda's origins are discussed by L.C. Soley in Radio Warfare: OSS and CIA Subversive Propaganda (1989). Older works include James Aronsen, The Press and the Cold War (1970) and J.C. Clews, Communist 
Propaganda Techniques (1964) and Richard H. Scultz and Roy Godson, Dezinformatsia: Active Measures in Soviet Strategy (1984). See also P. Biskind, Seeing is Believing: How Hollywood Taught Us to Stop Worrying and Love the Fifties (1983). Science fiction films from the period are reasonably well served in John Brosnan's The Primal Screen (1991), a largely personal labour of love, as is Stephen E. Pease, Psywar: Psychological Warfare in Korea, 1950-53 (1992). V. Kortunov, The Battle of Ideas in the Modern World (Moscow, 1979) and Georgi Arbatov, The War of Ideas in Contemporary International Relations (Moscow, 1973) reveal how the Soviets viewed the ideological struggle in the Cold War. A more dispassionate analysis is to be found in Marian Leighton, Soviet Propaganda as a Foreign Tool (1991). The Gorbachev era is covered by L. Bittman, The New Image Makers: Soviet Propaganda and Disinformation Today (1988). The reference in the text to the early 1960s work of Whitton and Larson is Propaganda: Towards Disarmament in the War of Words (1964). A new study of international radio is P.C. Wasburn, Broadcasting Propaganda: International Radio Broadcasting and the Construction of Political Reality (1992) which complements K.R.M. Short (ed.), Broadcasting over the Iron Curtain (1986) and Laurien Alexandre, The Voice of America: From Detente to the Reagan Doctrine (1988).

Vietnam has been best served by Daniel Hallin, The Uncensored War: The Media and Vietnam (1986), Peter Braestrup, Big Story: How the American Press and Television Reported and Interpreted the Crisis of Tet 1968 in Vietnam and Washington (1977), Michael Arlen, Living Room War (1982) and C.R. Wyatt, Paper Soldiers (1993). The subsequent film treatment of the war has been covered by Gilbert Adair, Hollywood's Vietnam (1987). Bruce Cumings' War and Television (1992) should have been called 'War on television' as he rails against the medium.

The Gulf War has produced a plethora of works of mixed quality, but attention is drawn to David E. Morrison, Television and the Gulf War (1992), Douglas Kellner, The Persian Gulf TV War (1993), Bradley S. Greenberg and Walter Gantz (eds), Desert Storm and the Mass Media (1993), John R. MacArthur, Censorship and Propaganda in the Gulf War (1992) and Hedrick Smith, The Media and the Gulf War: The Press and Democracy in Wartime (1992) as correctives to my own work (listed below). The best insight so far into what was really happening in the Gulf War, as distinct from the media images, is Rick Atkinson's Crusade (1994).

On modern military-media relations, A. Hooper's The Military and the Media (1982) has now received an invaluable supplement in the form of Jacqueline Sharkey, Under Fire: U.S. Military Restrictions on the Media 
from Grenada to the Persian Gulf and a short pamphlet by Steven Badsey, Modern Military Operations and the Media (1994). Sharkey's wellresearched 1993 book in fact also contains chapters going back to Vietnam and the Falklands. But David E. Morrison and Howard Tumber's Journalists at War: The Dynamics of News Reporting in the Falklands War (1988) contains the best insight into the experience of the reporters with the Task Force in the South Atlantic - sociology in the service of future historians. A general view of that conflict is Valerie Adams, The Media and the Falklands Campaign (1986) and a good read is to be found in Robert Harris, Gotcha! The Media, the Government and the Falklands Crisis (1983), although the House of Commons Defence Committee's first report on The Handling of Press and Public Information during the Falklands Conflict (2 vols, 1982) is perhaps the best starting point. Derrik Mercer, Geoff Mungham and Kevin Williams, The Fog of War: The Media on the Battlefield (1987) is not only vital for the Falklands but also for case studies elsewhere.

Equally variable in quality are works by media studies scholars who have yet to embrace the notion of propaganda as a central concern. Most who have tend to rely on the works of Noam Chomsky but such works as Manufacturing Consent: The Political Economy of the Mass Media (1988, with Edward Herman), Beyond Hypocrisy: Decoding the News in an Age of Propaganda (1992, also with Herman), Deterring Democracy (1991) and Necessary Illusions: Thought Control in Democratic Societies (1989) need to be read with caution. A short lesson on cock-ups in history rather than conspiracies needs to be issued with these as a health warning to students, especially those who believed that Oliver Stone's film J.F.K. was historically accurate. That said, they do stimulate the forewarned and they do provide compelling evidence of the mainstream American media's inability to accommodate opposing or dissenting viewpoints. Inside explanations of how the media actually work tend to come from practitioners from within the system, especially Mort Rosenblum's Who Stole the News? Why We Can't Keep Up With What Happens in the World (1993), Peter Arnett's Live from the Battlefield (1994), and Robert Weiner, Live from Baghdad: Gathering News at Ground Zero (1992). For a British perspective on reporting in the Gulf War, see John Simpson, From the House of War (1991), Patrick Bishop, Famous Victory (1992), Ben Brown and David Shukman, All Necessary Means (1991) and Alex Thomson, Smokescreen: The Media, The Censors, The Gulf (1992).

On combat morale, readers should consult John Keegan's The Face of Battle (1976), F.M. Richardson's Fighting Spirit (1978) and Richard 
Holmes' Firing Line (1985). And on possible futures, see Alvin and Heidi Toffler, War and Anti-War: Survival at the Dawn of the 21st Century (1994). As that book borrowed from the first edition of this one, I am happy to reciprocate.

My own contributions to this subject are principally The Projection of Britain: British Overseas Publicity and Propaganda, 1919-39 (1981), British Propaganda during the First World War (1982, with Mike Sanders), A Call to Arms: Propaganda and Rearmament in the 1930s (1984, pamphlet and film produced by the InterUniversity History Film Consortium), Britain and the Cinema and the Second World War (1988, as editor) and War and the Media: Propaganda and Persuasion in the Gulf War (1992).

Invaluable journals are The Historical Journal of Film, Radio and Television, Public Opinion Quarterly and Media Studies Journal.

Since the last edition of this book, several important works have appeared. These include Susan Carruthers' The Media at War (2000), Nancy Snow's Propaganda Inc: Selling America's Culture to the World (2nd edition, 2002), Alvin Snyder's Warriors of Disinformation: American Propaganda, Soviet Lies and the Winning of the Cold War (1997) and Walter Hixson's Parting the Curtain: Propaganda, Culture and the Cold War (1997). Historians continue to produce excellent works, such as Nicholas Reeves' The Power of Film Propaganda: Myth or Reality (2000) and James Chapman's The British at War, Cinema, State and Propaganda 1939-45 (2000). But now that the internet is more widely available, bibliographical searches have become simple. There are also numerous websites that are becoming valuable resources, many of which can be accessed via my own at www.leeds.ac.uk/ics/phillink.htm.

These are but a fraction of the works I have consulted over the years, not to mention the huge amount of documentary material, published and unpublished, in a whole host of places. But special mention must be made of the debt all propaganda historians owe to David Culbert, the series editor of the monumental collection of documents, Film and Propaganda in America (5 vols, 1990-3). But to all authors who have dedicated their time, energy and attention to this area, living and deceased, my thanks. 